\title{
Individual returns to education in the Spanish tourism sector during the economic crisis
}

\author{
Adelaida Lillo-Bañuls and José M. Casado-Díaz
}

Departamento de Análisis Económico Aplicado and Instituto Universitario de Investigaciones Turísticas (IUIT), Universidad de Alicante, Ap. Correos 99, E-03080 Alicante, Spain. E-mail: alillo@ua.es; jmcasado@ua.es. (Corresponding author: Adelaida Lillo-Bañuls.)

This paper analyses individual returns to education in the Spanish tourism sector. The results, which are robust to different specifications of Mincer earnings regressions, show that the earnings returns to schooling for tourism workers are only half those for all other sectors, and that the difference in returns between these two groups has increased significantly during the economic crisis. This has happened at a time when the earnings range between those with lower and higher qualifications has narrowed in tourism while it has remained stable in other sectors, and when tourism has been capable of retaining most of its workforce while the rest of the economy has experienced a sharp decrease in employment.

Keywords: human capital; returns to education; gender differences; over-education; economic crisis; Spain

JEL classification: J24; I21

The tourism sector comprises many different activities offering services to both tourists and residents, making it difficult to measure employment and added value in the sector, which is usually identified with a range of services including hotel and restaurant services (the most representative segment of the sector), transport, travel agencies and tour operators and leisure, cultural and sporting activities. The sum of these subsectors constitutes a major economic activity with a broadly positive impact on economic growth and employment in Europe (European Commission, 2010), which is especially important in Spain. As an Organisation for Economic Co-operation and Development (OECD) country, the tourism sector has the highest relative weight in terms of employment $(13 \%)$ and gross added value (11\%) according to 2009 data.

It is well known that the tourism sector is characterized as a low-tech and traditionally labour-intensive industry and, particularly in the hotel and restaurant subsector, by a greater presence of women, young people and immigrants among its workforce. It is also a sector that has a high capacity for 
retaining its workforce or even generating employment in periods of low economic growth. Thus, for example, data from 2007 to 2010 - referring to the evolution of the number of people registering with the Spanish Social Security in the tourism sector - show that a reduction in tourism sector workers occurred $(2.2 \%)$ in 2009 only. However, in the economy as a whole, the decrease began a year earlier and, after a particularly sharp fall in $2009(5.7 \%)$, continued in 2010 - a year when the tourism sector was already experiencing net increases in Social Security registrations. The significant contribution of the tourism industry to economic growth has been well documented in a growing number of empirical analyses (see for example Brau et al, 2007; and Cortés-Jiménez, 2008). This evidence was recently corroborated and extended by Di Liberto (2010), who used a large international panel dataset covering a long period of time and found that despite being a low-tech, low skill sector, the positive effects of tourism specialization on economic growth are reinforced by higher human capital endowments.

The working conditions in tourism have frequently been described in terms of their negative features. In the case of Spain, for example, the White Paper on Human Resources in the Tourism Sector (Exceltur, 2004) reported that the tourism labour market is characterized by uncomfortable working hours (including bank holidays, weekends, and evening and night shifts), longer weekly working hours than in other sectors, uncompetitive wages, jobs that require few or no qualifications, low investment in training, poor career prospects and low external recognition and social prestige, among other aspects.

Thus, on the one hand tourism is a very important economic sector in Spain, with a high capacity to generate employment, even during the more difficult moments of the recent economic cycle and one which employs some of the most disadvantaged groups in the labour market. On the other hand, but not independently of this fact, tourism comprises a series of activities where human capital intensity is lower than elsewhere, and which are characterized by low levels of productivity. A less-educated workforce is, in principle, less inclined to generate and/or adopt innovations of any kind (technological, organizational, etc); it has a lower capacity to adapt to change and fewer possibilities, therefore, for contributing to improving the competitiveness of the sector in a context of increasing international competition. Without a doubt, a large part of the capacity to address the challenges the sector is facing will arise from improvements in its human capital (Lillo-Bañuls, 2009b).

This paper analyses different aspects of human capital in the Spanish tourism sector during the economic crisis and concentrates on the measurement of individual returns to education in this period. Human capital denotes the knowledge, competences and useful skills that are accumulated by individuals in the process of education and training throughout their working lives. One of the most frequently used theoretical frameworks for analysing the earnings aspects of human capital is the one proposed by Becker (1964). This framework is based on the idea that investing in education increases the productivity of workers and, therefore, that the earnings of those who have spent more years studying are higher. Based on this theory, the calculation of the rate of returns to education seeks to measure the relationship that exists between the income of individuals and their education. This is a branch of literature that has received multiple empirical additions in the last 50 years, although most 
international contributions focusing on tourism are relatively recent. For example, see Lillo-Bañuls and Ramón-Rodríguez (2005), Lillo-Bañuls (2009a), Muñoz-Bullón (2009), Lillo-Bañuls and Casado-Díaz (2010), Marchante et al (2005), Campos-Soria et al (2009 and 2011), García-Pozo et al (2011) and García-Pozo et al (2012), who concentrated on the Spanish tourism industry; Santos and Varejão (2007), who analysed the Portuguese case; and Thrane (2008 and 2010), who examined diverse aspects of the education-earnings relationship in the Norwegian tourism industry.

The paper is organized as follows: the next section presents the econometric specifications, which are variations of Mincer earnings regressions, and the data used, which stem from the Quality of Life at Work Survey (ECVT) - a survey conducted annually by the Spanish Ministry of Employment and Immigration. An exploratory analysis confirms some of the negative characteristics that the literature assigns to the tourism labour market, such as a greater incidence of part-time and fixed-term contracts, and lower hourly earnings compared to the rest of the economy. It is also notable that although educational levels are, on average, lower in tourism (especially at university level), the incidence of overeducation is, however, higher in this sector than in others. This is followed by a section that reports and discusses the results, according to which a considerable difference exists in the main period of analysis (2008-2010) between the individual returns to education in tourism and in the rest of the sectors. Moreover, the analysis conducted for the preceding year provides a reference point that indicates that the difference in the returns to education between both groups has increased during the crisis. Some explanations for this phenomenon are explored in this section. The magnitude of the difference in the returns to education between tourism and the rest of the sectors is robust to the diverse specifications reported here, where the traditional Mincer model is extended through the inclusion of additional covariates, one of which is educational mismatch. The conclusions are presented in the last section.

\section{Econometric specifications and data}

\section{Econometric specifications}

In order to calculate private returns to education, diverse specifications of the Mincer earnings equations (1974) have been used. In its original formulation (1), this Mincerian equation estimates the effect of individuals' education and work experience on their wage earnings:

$$
\log W_{i}=\beta_{o}+\beta_{1} S_{i}+\beta_{2} X_{i}+\beta_{3} X_{i}^{2}+u_{i},
$$

where $i$ is a subscript for individuals $(i=1,2, \ldots, n)$, the dependent variable, earnings $W_{i}$, adopts a logarithmic form whereby the estimated coefficients may be interpreted in terms of rates of return, $S_{i}$ refers to years of schooling, $X_{i}$ is years of work experience (this variable is also included as a squared term) and $u_{i}$ is a random error term. In Equation (1), education appears as a continuous variable - the number of years of schooling - and the estimated coefficient can be interpreted as the elasticity of income-education, namely, the expected value 
of the partial derivative of the logarithm of income with respect to the schooling received. Therefore, $\beta_{1}$ represents the increase in pay of each additional year of schooling, which, in the absence of direct costs, is equal to the IRR (Internal Rate of Return). In Equation (1) it is assumed that the marginal returns to education are constant. This assumption is relaxed in Equation (2), where education is considered in discrete terms and the coefficients $\beta_{1}-\beta_{3}$ may be used to estimate the earnings premiums that, in relation to the reference category ( $E_{1}$, primary schooling), are obtained by individuals who have completed basic secondary education $\left(E_{2}\right)$, professional training $\left(E_{3}\right)$, baccalaureate $\left(E_{4}\right)$ or university studies $\left(E_{5}\right)$.

$$
\log W_{i}=\beta_{o}+\beta_{1} E_{2}+\beta_{2} E_{3}+\beta_{3} E_{4}+\beta_{4} E_{5}+\beta_{5} X_{i}+\beta_{6} X_{i}^{2}+u_{i} .
$$

Equations (1) and (2) were estimated for two different periods ${ }^{1}$ with the aim of assessing how the returns to education have evolved during the crisis period compared to the pre-crisis period, for both the tourism sector and the rest of the economy (Table 2). Separate estimations were conducted for male and female workers.

Diverse extended versions of Equation (1) were also considered, in which additional explanatory variables were included either separately (Tables 4 and A2) or simultaneously (Table 5). The aim of this strategy was to test the stability of the estimated returns to education across different specifications of the model, while at the same time allowing the assessment of the effects of each of the covariates on such returns.

\section{Data and variables}

The data used refer to wage earners aged between 16 and 64 and stem from the ECVT, a source that provides information referring to the year 2007 and is the base from which a pool for the crisis period 2008-2010 was also constructed. This survey contains information about workers who are employed in firms of any size, even those with only one worker, which is particularly important when analysing a sector such as tourism, characterized by many small companies. It is worth highlighting that this statistical source allows a good estimation of the real experience of the worker as it indicates the year when the worker began to work for the first time. It also includes variables that make it possible to analyse other important human capital related aspects such as educational mismatches or the satisfaction of workers in terms of different aspects of their working conditions.

The dependent variable in all the specifications is the logarithm of net earnings per effective working hour. This was calculated by combining the information that the statistical source provides on both monthly earnings and the number of hours worked per week. The variable Education $\left(S_{i}\right)$ in Equation (1) refers to years of formal education. Following standard practice, this was calculated using information on the maximum level of education attained by the respondent, by assigning to each of these levels the minimum number of years necessary for their completion. This second variable is the one used in Equation (2), where the reference category, E1, is primary schooling and the rest of the categories refer to those who have completed basic secondary education, E2, professional training, E3, baccalaureate, E4, or university studies, 
E5. Experience $\left(X_{i}\right)$ was calculated using the information provided about the time when the individual actually started to work. ${ }^{2}$ This approach avoids the inaccuracy of the most frequently used alternative, where experience is proxied by age minus years of schooling (usually the minimum number of years necessary to complete the declared level of education), minus six. This second method overestimates the experience of employees who have taken more than the statutory number of years to obtain a qualification and of those who have taken longer to find a job (something very relevant in a country where youth unemployment is especially high). All the estimations in the article include controls for the year of reference when they are based on pooled data (that is, those for the period 2008-2010).

The extended models subsequently considered in Tables 4, A2 and 5 incorporate additional explanatory variables. The first of these is educational mismatch, which is included through a set of discrete variables that refer to wage earners who define themselves as appropriately educated (reference category), over-educated, under-educated or in need of different training in relation to their current job. A direct subjective method was used here, according to which the worker was classified as over-educated or not depending on his/her response to the question asking whether he/she considered his/her level of education to be sufficient for carrying out his/her current job. Type of contract is a variable that has two categories in the statistical source: fixed-term/ temporary (reference category) and indefinite. A variable distinguishing between full-time (reference category) and part-time work has also been considered. Nationality distinguishes between two categories: Spanish (this is the reference category and also includes individuals with dual nationality in those cases where Spanish is one of them) and all other nationalities (in this category, the presence of individuals from other advanced economies according to the International Monetary Fund [IMF] classification was residual). The variable firm size, which is measured in terms of number of employees, has four categories: 1-9 (reference category), 10-49, 40-249 and 250+. Following Ammermueller et al (2009), a continuous variable capturing the logarithm of the regional unemployment rate has also been included. To construct this, each individual was assigned the annual average unemployment rate registered in his/ her region of residence, using the Labour Force Survey as the source. Lastly, controls were included for the six Spanish regions where tourist inflow is above average.

The descriptive analysis in Table 1 confirms a fact that has been wellestablished in the literature on human capital in the tourism sector: its low levels of education compared to other economic activities. ${ }^{3}$ Approximately $50 \%$ of wage earners are concentrated in the two lowest levels of schooling, primary (E1) and basic secondary (E2), which is almost 14 percentage points higher than figures for the rest of the economy. On the other end of the educational scale, the percentage of university graduates $(13.73 \%)$ is less than one-half that of all other economic activities. It is worth noting, however, that these figures have increased slightly with respect to those estimated by Lillo-Bañuls and RamónRodríguez (2005), based on the same statistical source for the period 19992002. These authors found that workers with primary and basic secondary education accounted for $57 \%$ of the total tourism sector and university graduates accounted for $11 \%$. 
Table 1. Description of statistics for the main study variables, 2008-2010.

\begin{tabular}{|c|c|c|c|c|c|c|}
\hline & & st of sect & & & Tourism & \\
\hline & Total & Women & Men & Total & Women & Men \\
\hline Education (years) & $\begin{array}{l}10.99 \\
(4.06)\end{array}$ & $\begin{array}{l}11.67 \\
(3.99)\end{array}$ & $\begin{array}{l}10.46 \\
(4.03)\end{array}$ & $\begin{array}{l}9.66 \\
(3.55)\end{array}$ & $\begin{array}{c}9.91 \\
(3.68)\end{array}$ & $\begin{array}{c}9.48 \\
(3.45)\end{array}$ \\
\hline Level of education: & & & & & & \\
\hline $\operatorname{Primary}\left(E_{1}\right)^{*}$ & $16.63 \%$ & $12.65 \%$ & $19.84 \%$ & $20.76 \%$ & $20.44 \%$ & $20.99 \%$ \\
\hline Secondary $\left(E_{2}\right)$ & $20.17 \%$ & $17.22 \%$ & $22.54 \%$ & $29.60 \%$ & $26.66 \%$ & $31.68 \%$ \\
\hline Professional training $\left(E_{3}\right)$ & $21.54 \%$ & $20.73 \%$ & $22.20 \%$ & $19.43 \%$ & $17.43 \%$ & $20.85 \%$ \\
\hline Baccalaureate $\left(E_{4}\right)$ & $12.54 \%$ & $13.37 \%$ & $11.84 \%$ & $16.47 \%$ & $18.78 \%$ & $14.85 \%$ \\
\hline University $\left(E_{5}\right)$ & $29.11 \%$ & $36.03 \%$ & $23.55 \%$ & $13.73 \%$ & $16.70 \%$ & $11.63 \%$ \\
\hline Hourly earnings $(€)$ & $\begin{array}{c}8.63 \\
(6.01)\end{array}$ & $\begin{array}{c}8.50 \\
(6.39)\end{array}$ & $\begin{array}{c}8.73 \\
(5.68)\end{array}$ & $\begin{array}{c}7.51 \\
(4.33)\end{array}$ & $\begin{array}{c}6.97 \\
(4.19)\end{array}$ & $\begin{array}{r}7.89 \\
(4.39)\end{array}$ \\
\hline Experience (years) & $\begin{array}{c}20.09 \\
(11.69)\end{array}$ & $\begin{array}{c}18.59 \\
(11.30)\end{array}$ & $\begin{array}{c}21.29 \\
(11.85)\end{array}$ & $\begin{array}{c}19.18 \\
(11.68)\end{array}$ & $\begin{array}{c}17.02 \\
(11.15)\end{array}$ & $\begin{array}{c}20.70 \\
(11.81)\end{array}$ \\
\hline Fixed-term contract ${ }^{*}$ & $21.21 \%$ & $23.11 \%$ & $19.69 \%$ & $26.30 \%$ & $29.56 \%$ & $23.99 \%$ \\
\hline Indefinite contract & $78.79 \%$ & $76.89 \%$ & $80.31 \%$ & $73.70 \%$ & $70.44 \%$ & $76.01 \%$ \\
\hline Full-time ${ }^{*}$ & $87.03 \%$ & $77.95 \%$ & $94.33 \%$ & $82.54 \%$ & $73.13 \%$ & $89.17 \%$ \\
\hline Part-time & $12.97 \%$ & $22.05 \%$ & $5.67 \%$ & $17.46 \%$ & $26.87 \%$ & $10.83 \%$ \\
\hline Nationality & & & & & & \\
\hline Spanish $^{*}$ & $90.94 \%$ & $91.52 \%$ & $90.48 \%$ & $81.17 \%$ & $78.11 \%$ & $83.82 \%$ \\
\hline Other nationalities & $9.06 \%$ & $8.48 \%$ & $9.52 \%$ & $18.83 \%$ & $21.89 \%$ & $16.68 \%$ \\
\hline Firm size (no. of employees) & & & & & & \\
\hline $1-9^{*}$ & $21.88 \%$ & $22.65 \%$ & $21.26 \%$ & $33.25 \%$ & $37.34 \%$ & $30.36 \%$ \\
\hline $10-49$ & $21.32 \%$ & $18.55 \%$ & $23.55 \%$ & $26.17 \%$ & $24.38 \%$ & $27.43 \%$ \\
\hline $50-249$ & $16.51 \%$ & $15.68 \%$ & $17.18 \%$ & $15.02 \%$ & $13.38 \%$ & $16.17 \%$ \\
\hline 250 or more & $40.29 \%$ & $43.13 \%$ & $38.00 \%$ & $25.57 \%$ & $24.90 \%$ & $26.04 \%$ \\
\hline Educational mismatch & & & & & & \\
\hline Appropriately educated* & $77.74 \%$ & $74.9 \%$ & $80.11 \%$ & $73.23 \%$ & $68.98 \%$ & $76.23 \%$ \\
\hline Over-educated & $18.48 \%$ & $21.82 \%$ & $15.81 \%$ & $22.39 \%$ & $25.41 \%$ & $20.26 \%$ \\
\hline Under-educated & $1.94 \%$ & $1.66 \%$ & $2.16 \%$ & $1.93 \%$ & $2.59 \%$ & $1.46 \%$ \\
\hline In need of different training & g $1.84 \%$ & $1.74 \%$ & $1.93 \%$ & $2.45 \%$ & $3.01 \%$ & $2.05 \%$ \\
\hline
\end{tabular}

Note: Continuous variables: mean and standard deviation - in parentheses; discrete variables: percentage of total number of employees in the category. "Reference category in regressions in Tables 2 , 4,5 , and A2.

Source: Authors' own calculations based on the Quality of Life at Work Survey (ECVT), 2008-2010 (Spanish Ministry of Employment and Immigration).

With regards to workforce composition, approximately $19 \%$ of tourism workers are immigrants - a proportion that is more than double that of the rest of the Spanish economy $(9.06 \%)$. The values for the other variables included in Table 1 show that hourly earnings are lower in tourism than in other economic activities (€7.51 versus €8.63), something that is especially evident in the case of women ( $€ 6.97$ versus $€ 8.50$ ), and that the incidence of fixed- 
term and part-time contracts is higher in tourism compared to the rest of the Spanish economy (26.30\% versus $21.21 \%$ and 17.46 versus $12.97 \%$, respectively). According to Table 1, very small firms are much more abundant in the Spanish tourism industry compared to the rest of the economy: whereas the proportion of tourism workers in firms with less than 10 employees is $33.25 \%$, this figure is almost 12 percentage points lower in the rest of the sectors $(21.88 \%)$.

Table 1 also explores another variable that should be considered together with education when analysing tourism's human capital - educational mismatch. The data show that over-education affects around $22.4 \%$ of those working in the tourism services ${ }^{4}$ versus $18.5 \%$ in the rest of the sectors. It is worth pointing out that this phenomenon seems to become more pronounced over time. Therefore, according to Lillo-Bañuls (2009b), who pooled data from cross sections of the same source for the period 1999-2002, over-education affected $19 \%$ of workers in tourism services. These results are consistent with other analyses referring to the Spanish economy as a whole, which have also revealed an increase in the incidence of this phenomenon using other analytical techniques (Aguilar and García-Crespo, 2008; Murillo et al, 2010). According to García-Montalvo and Peiró (2009) this fact is largely explained by an excess supply of qualified workers in relation to the demand for their services, something that might be more pronounced in the case of tourism: between the academic years 1988/1989 and 2008/2009, the number of students enrolled in the Tourism Diploma multiplied by 2.5 within a context in which enrolments in general fell by approximately 25\% (INE, 2010).

One of the main conclusions from this descriptive section examining human capital in tourism is that although the educational levels of those working in this sector are lower than in the rest of the economy, the incidence of overeducation is higher. The potentially negative effects of such a combination cannot be ignored. As stated earlier, a less-educated workforce is, in principle, less inclined to adopt innovations and has a lower capacity to adapt to change or contribute to improving the competitiveness of the sector. From a social point of view, it seems evident that over-qualification is an indication of a failure in the allocation of productive resources - a part of which lie idle with respect to the human capital of the individuals concerned. Moreover, overeducation reduces workers' motivation and well-being, which could have a negative effect on productivity, giving rise to the paradox whereby better qualified workers could prove to be less productive if the characteristics of their jobs do not correspond to their training. In the following section, the impact of over-education on earnings and on individual returns to education is one of the aspects discussed.

\section{Results}

\section{Basic model}

Table 2 includes the results of the ordinary least squares (OLS) regression analysis based on Equations (1) and (2). From Table 2, it is clear that independently of the group of activities considered, a higher level of education 


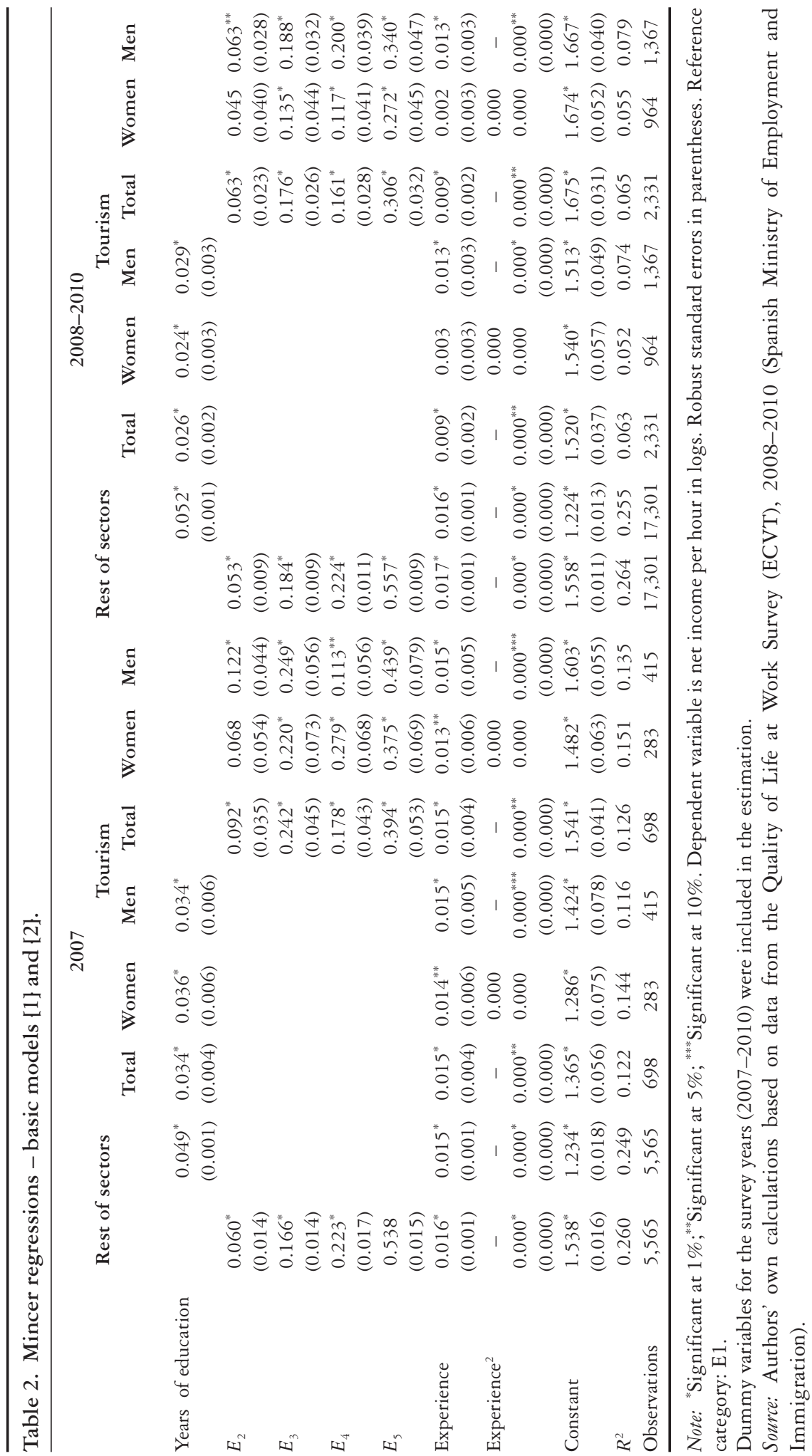


Table 3. Differences between educational levels, 2008-2010.

Rest of sectors (\%)

Tourism

Total (\%) Women $(\%)$

$\operatorname{Men}(\%)$

6.56

4.60

6.50

$19.23 \quad 14.50$

20.60

17.39

12.40

22.03

35.74

31.26

40.37

Source: Authors' own calculations based on the results reported in Table 2.

is associated with higher earnings, in line with theoretical predictions. This is shown by the positive sign of the estimated coefficient for the variable years of education and is particularly clear with the estimates of Equation (2). Thus, Table 3 displays the additional remuneration received by those who have obtained each subsequent level of education in relation to the reference category, ${ }^{5}$ that of primary schooling $\left(E_{1}\right)$. The differences are particularly pronounced in the case of university graduates, whose earnings are $74.65 \%$ higher than the earnings of those who have only received primary education in the sample that excludes those working in the tourism sector.

According to Table 2, for the period 2008-2010, individual returns to every year of additional schooling were considerably lower for tourism workers $(2.6 \%)^{6}$ than for those working in all other economic activities (5.2\%) - a fact that is also observable in 2007 (3.4\% and $4.9 \%$, respectively), differences which in all cases are statistically significant at the $1 \%$ level.

The same conclusion is reached when the estimation of model (2) is analysed. The results show that the difference in the returns to education between tourism and the rest of the economy is especially high among those holding a university degree or baccalaureate (an educational track specially designed to qualify for studies at university level) as their highest completed educational qualification. According to Table 3, the earnings returns to education for university graduates working in tourism are only $35.74 \%$ higher than they are for those with primary education (less than half of the premium in the rest of the sectors), while the relative reward is $17.39 \%$ for tourism workers holding a baccalaureate (25.10\% in the rest of the economy).

It is noteworthy that the difference in individual returns to education for workers between the tourism sector and the rest of the economy has increased. Thus, in 2007, returns in the tourism sector were $69.4 \%$ of the levels of returns corresponding to the rest of the economy (a figure comparable with that obtained by Lillo-Bañuls (2009a), using similar data for the period 1999-2002), whereas in the period 2008-2010 this figure only reached 50\% (Table 2). The main reason for this increasing gap is the reduction in the returns to education among tourism workers ${ }^{7}$ (from 3.4 to 2.6 , significant at the $1 \%$ level), which happened in a period without relevant changes in average schooling since the very slight increase in the average years of education that can be observed was higher in the rest of the economy than in the tourism sector. One possible explanation for this phenomenon is the behaviour of employment in the sector during the economic crisis; the number of officially registered workers 
employed in tourism activities remained stable between 2007 and 2010 (a fall of $0.2 \%$ ), as opposed to the reduction of $8.2 \%^{8}$ experienced by the Spanish economy as a whole. The data indicate that while the economic crisis may have generated an adjustment in the Spanish labour market, particularly through a high level of job destruction, in tourism activities wage restraints may have been applied, which in turn would have differentially and negatively affected the returns to education of the workers in the sector. This interpretation is coherent with the evolution of hourly earnings: on average, these increased by $6.22 \%$ between 2007 and 2008-2010 for tourism workers, while the figure was $9.51 \%$ for those working in the rest of the sectors (Tables 1 and A1). However, in the case of those holding university degrees, the hourly earnings in tourism did not change $(-0.22 \%)$ whereas they grew by $7.28 \%$ in the rest of the sectors. ${ }^{9}$ As a result of this evolution, the difference in average hourly earnings between the group of workers holding university degrees and those for whom primary education is their highest completed educational level decreased between both periods from around $51 \%$ to $33 \%$ for tourism workers, while it remained stable (around $70 \%$ ) for the rest of the economy.

With respect to work experience, Table 2 shows that experienced workers receive a lower earnings premium in the tourism sector than in the rest of the economy; this is especially true among female tourism workers, for whom the variable experience is not significant. This circumstance, which is confirmed both when education is considered as a continuous variable and when it is introduced as a series of dummy variables, could be related to some of the less attractive characteristics of employment in the sector; namely, high seasonality and job turnover and the low training requirements commonly associated with such work. It seems clear then that both official qualifications and the acquisition of skills and abilities through work experience are less valued in the tourism sector than in the rest of the economy.

\section{Including other variables in the model}

In order to analyse the possible influence of educational mismatch and other relevant variables on the economic returns to education, a more comprehensive specification of Equation (1) has been estimated in this section, where a number of additional covariates has been included both separately (Tables 4 and A2) and simultaneously (Table 5).

Starting with Table 4, where educational mismatch is considered in addition to the variables in Equation (1), the estimated coefficient for over-education has a negative sign and is significant in the samples analysed. However, the coefficients corresponding to the under-education variable are not significant, while those corresponding to workers who state that they need a different type of training are not significant in the estimation for the tourism sector. The results reveal, therefore, that over-educated workers obtain a lower remuneration than those who have similar levels of education and experience and occupy jobs for which they are appropriately trained. Specifically, the expected value of the wage differences between an over-educated worker with respect to the reference category (appropriately educated) is a reduction of $11.5 \%$ in tourism and $18.9 \%$ in the rest of the sectors. ${ }^{10}$ It is interesting to note that in this case, the penalty suffered by tourism workers is lower than that experienced by those working 
Table 4. Mincer regressions including educational mismatch, 20082010.

Rest of sectors

Years of education

Over-educated

Under-educated

In need of different training

Experience

Experience $^{2}$

Constant

$R^{2}$

Observations

$\begin{array}{cc}0.055^{*} & 0.030^{*} \\ (0.000) & (0.002) \\ -0.173^{*} & -0.109^{*} \\ (0.008) & (0.020) \\ 0.023 & 0.034 \\ (0.020) & (0.072) \\ -0.062^{*} & -0.006 \\ (0.19) & (0.067) \\ 0.015^{*} & 0.008^{*} \\ (0.001) & (0.002) \\ -0.000^{*} & -0.000 \\ (0.000) & (0.000) \\ 1.240^{*} & 1.522^{*} \\ (0.124) & (0.037) \\ 0.278 & 0.007 \\ 17,301 & 2,331\end{array}$

Note: Dependent variable is hourly net earnings in logs. Significance levels: ${ }^{*} 1 \%$, ${ }^{* *} 5 \%,{ }^{* * *} 10 \%$. All specifications include controls for the survey year. Robust standard errors are reported in parentheses. 'Appropriately educated' is the reference category for the variable reflecting educational mismatch.

Source: Authors' own calculations based on data from the Quality of Life at Work Survey (ECVT), 2008-2010 (Spanish Ministry of Employment and Immigration).

in the wider economy, although this occurs within a context in which the wages of tourism workers are lower than average, as are the returns to education according to the years of schooling.

The inclusion in model (1) of variables that capture educational mismatch results in an increase in the estimated returns to education in relation to the results reported in Table 2. Thus, as opposed to $2.6 \%$ (tourism) and $5.2 \%$ (rest of the sectors), estimated returns to education in Table 4 are $3 \%$ and $5.5 \%$, respectively. It is therefore obvious that the returns to education suffer a downward bias when over-education is not taken into account: according to this result, the years of over-education would have a lower return than the years spent in acquiring the training required for the job. Hence, when considering all the years of formal education of the individual jointly and equally, the average return of each of them is lower. These results contradict, at least partially, the assumptions of the human capital theory, which associates productivity and wages with the level of education, since this theory implies that the returns to education should be independent of whether the worker is over-educated or not. However, the results may be more compatible with theories based on job competition (Thurow, 1970), which contend that the worker is essentially compensated in accordance with the position that he/she occupies rather than his/her level of education. If a worker has a higher level of academic training than is required to carry out his/her job, this circumstance is not paid. The worker will only be remunerated for the tasks carried out within his/her 
Table 5. Mincer regressions - extended model, 2008-2010.

\begin{tabular}{|c|c|c|c|c|c|c|}
\hline & & est of sectc & & & Tourism & \\
\hline & Total & Women & Men & Total & Women & Men \\
\hline Years of education & $0.049^{*}$ & $0.056^{*}$ & $0.046^{*}$ & $0.026^{*}$ & $0.025^{*}$ & $0.028^{*}$ \\
\hline & $(0.000)$ & $(0.001)$ & $(0.001)$ & $(0.002)$ & $(0.003)$ & $(0.003)$ \\
\hline Fixed-term contract & $0.061^{*}$ & $0.023^{* *}$ & $0.090^{*}$ & $0.051^{*}$ & -0.004 & $0.090^{*}$ \\
\hline & $(0.007)$ & $(0.011)$ & $(0.009)$ & $(0.019)$ & $(0.027)$ & $(0.026)$ \\
\hline Part-time contract & $0.142^{*}$ & $0.224^{*}$ & $0.088^{*}$ & $0.202^{*}$ & $0.290^{*}$ & $0.171^{*}$ \\
\hline & $(0.010)$ & $(0.012)$ & $(0.019)$ & $(0.023)$ & $(0.029)$ & $(0.037)$ \\
\hline Born in a foreign & $-0.076^{*}$ & $-0.077^{*}$ & $-0.084^{*}$ & $-0.067^{*}$ & $-0.074^{* *}$ & $-0.060^{* * * *}$ \\
\hline country & $(0.010)$ & $(0.017)$ & $(0.012)$ & $(0.022)$ & $(0.029)$ & $(0.032)$ \\
\hline Firm size: $10-49$ & $0.062^{*}$ & $0.066^{*}$ & $0.047^{*}$ & $0.075^{*}$ & $0.080^{* * *}$ & $0.061^{* *}$ \\
\hline employees & $(0.008)$ & $(0.013)$ & $(0.010)$ & $(0.020)$ & $(0.032)$ & $(0.026)$ \\
\hline Firm size: $50-249$ & $0.104^{*}$ & $0.096^{*}$ & $0.105^{*}$ & $0.099^{*}$ & $0.070^{* *}$ & $0.095^{*}$ \\
\hline employees & $(0.009)$ & $(0.014)$ & $(0.011)$ & $(0.022)$ & $(0.035)$ & $(0.029)$ \\
\hline Firm size: 250 or & $0.165^{*}$ & $0.156^{*}$ & $0.174^{*}$ & $0.171^{*}$ & $0.111^{*}$ & $0.204^{*}$ \\
\hline more employees & $(0.007)$ & $(0.012)$ & $(0.009)$ & $(0.021)$ & $(0.030)$ & $(0.029)$ \\
\hline Over-educated & $-0.164^{*}$ & $-0.161^{*}$ & $-0.163^{*}$ & $-0.106^{*}$ & $-0.079^{*}$ & $-0.121^{*}$ \\
\hline & $(0.007)$ & $(0.010)$ & $(0.010)$ & $(0.020)$ & $(0.027)$ & $(0.028)$ \\
\hline Under-educated & 0.017 & -0.018 & 0.036 & 0.033 & -0.031 & 0.170 \\
\hline & $(0.020)$ & $(0.035)$ & $(0.023)$ & $(0.075)$ & $(0.079)$ & $(0.119)$ \\
\hline In need of & $-0.068^{*}$ & $-0.069^{* *}$ & $-0.078^{*}$ & -0.010 & -0.30 & $0.021)$ \\
\hline different training & $(0.018)$ & $(0.031)$ & $(0.020)$ & $(0.064)$ & $(0.086)$ & $(0.089)$ \\
\hline Log regional & $-0.140^{*}$ & $-0.101^{*}$ & $-0.179^{*}$ & $-0.134^{*}$ & -0.50 & $-0.192^{*}$ \\
\hline unemployment & $(0.017)$ & $(0.030)$ & $(0.020)$ & $(0.051)$ & $(0.095)$ & $(0.058)$ \\
\hline Region of residence: & $0.092^{*}$ & $0.073^{*}$ & $0.113^{*}$ & 0.047 & 0.035 & 0.045 \\
\hline Andalusia & $(0.015)$ & $(0.026)$ & $(0.017)$ & $(0.044)$ & $(0.078)$ & $(0.053)$ \\
\hline Region of residence: & $0.075^{*}$ & $0.076^{*}$ & $0.091^{*}$ & $0.064^{* * *}$ & 0.71 & $0.097^{* *}$ \\
\hline Balearic Islands & $(0.016)$ & $(0.024)$ & $(0.021)$ & $(0.034)$ & $(0.050)$ & $(0.046)$ \\
\hline Region of residence: & $0.040^{* *}$ & 0.020 & $0.067^{*}$ & 0.025 & 0.01 & 0.060 \\
\hline Canary Islands & $(0.019)$ & $(0.032)$ & $(0.023)$ & $(0.048)$ & $(0.076)$ & $(0.065)$ \\
\hline Region of residence: & $0.019^{*}$ & -0.000 & $0.049^{*}$ & 0.027 & 0.20 & $0.046^{* * *}$ \\
\hline Catalonia & $(0.007)$ & $(0.011)$ & $(0.008)$ & $(0.020)$ & $(0.032)$ & $(0.025)$ \\
\hline Region of residence: & $0.025^{* *}$ & 0.024 & $0.035^{* *}$ & 0.043 & 0.018 & 0.074 \\
\hline Valencian & $(0.012)$ & $(0.020)$ & $(0.015)$ & $(0.038)$ & $(0.057)$ & $(0.050)$ \\
\hline Community & & & & & & \\
\hline Region of residence: & $0.054^{*}$ & $0.033^{* *}$ & $0.083^{*}$ & $0.056^{* * *}$ & 0.063 & $0.067^{* * *}$ \\
\hline $\begin{array}{l}\text { Community of } \\
\text { Madrid }\end{array}$ & $(0.009)$ & $(0.014)$ & $(0.013)$ & $(0.031)$ & $(0.051)$ & $(0.037)$ \\
\hline Experience & $0.013^{*}$ & $0.011^{*}$ & $0.014^{*}$ & $0.007^{*}$ & 0.001 & $0.010^{*}$ \\
\hline & $(0.000)$ & $(0.001)$ & $(0.001)$ & $(0.002)$ & $(0.003)$ & $(0.003)$ \\
\hline Experience $^{2}$ & 0.000 & $0.000^{*}$ & $0.000^{*}$ & $0.000^{* * *}$ & 0.000 & $0.000^{* *}$ \\
\hline & $(0.000)$ & $(0.000)$ & $(0.000)$ & $(0.000)$ & $(0.000)$ & $(0.000)$ \\
\hline Constant & $1.478^{*}$ & $1.267^{*}$ & $1.613^{*}$ & $1.732^{*}$ & $1.561^{*}$ & $1.847^{*}$ \\
\hline & $(0.041)$ & $(0.069)$ & $(0.050)$ & $(0.115)$ & $(0.201)$ & $(0.139)$ \\
\hline$R^{2}$ & 0.319 & 0.322 & 0.357 & 0.146 & 0.185 & 0.167 \\
\hline Observations & 17,301 & 7,710 & 9,591 & 2,331 & 964 & 1,367 \\
\hline
\end{tabular}

Note: Dependent variable is hourly net earnings in logs. Significance levels: ${ }^{*} 1 \%,{ }^{* *} 5 \%,{ }^{* * *} 10 \%$. All specifications include controls for the survey year. Robust standard errors are reported in parentheses. Source: Authors' own calculations based on data from the Quality of Life at Work Survey (ECVT), 2008-2010 (Spanish Ministry of Employment and Immigration). 
job. As indicated by Aguilar and García-Crespo (2008), if, in accordance with job competition theory, wages depend on the educational level required for jobs, then the years of over-education would be unproductive.

The estimations of alternative specifications of Equation (1), in which several covariates are considered individually, are reported in Table A2. The signs of these additional estimated coefficients are similar for tourism and the rest of the economy (although the values vary): positive for both fixed-term and parttime contracts, as well as for all firm sizes included in the estimation (the reference category was 1-9 employees). As expected, the sign is negative for the constructed variable $\log$ regional unemployment. Most of the regional dummies are not significant for tourism. The most relevant conclusion, however, is that the gap in the individual returns to education between tourism and the rest of the economy remains largely unaltered throughout the various specifications, with the control for nationality being the variable that induces the minimum distance between both estimated returns to education ( 5.1 versus 2.7).

In Table 5, the traditional Mincer equation is extended through the simultaneous inclusion of all the covariates that were considered individually in Tables 4 and A2.

According to the results reported in Table 5, the individual returns to education in tourism are the same (2.6) in both the pure human capital model (Table 2) and the extended one (Table 5), while a slight reduction is observed in the rest of the sectors (from 5.2 to 4.9). A separate analysis for male and female workers shows that the gap is especially wide for women, whose returns are 2.5 in tourism and 5.6 in the rest of the economy, while for male workers the figures are 2.8 and 4.6, respectively. The signs of the estimated coefficients are the same as in Tables 4 and A2. Regarding educational mismatch, the hourly earnings of workers who classify themselves as over-educated are $17.82 \%$ $(\exp (0.164)-1=0.1782)$ lower than those within the reference category (appropriately educated), and $11.18 \%$ in the case of workers in the tourism sector. These figures are comparable to those in Table 4. As expected, aggregate regional unemployment has an inverse relationship with hourly wage. Finally, and with respect to experience, the coefficient suffers a comparable reduction (around 23\%) in the extended model for both tourism and the rest of the sectors, and therefore the distance between both parts of the economy remains constant in this regard (the figure for tourism being almost half that of the rest of the economy).

The evidence reported in Table 5, together with that of Tables 4 and A2, confirms that the main results are robust to the inclusion of additional variables: the individual returns to education continued to be significantly lower in the tourism sector than in the rest of the economy during the crisis, and this was also the case of the rewards associated with each year of work experience.

\section{Conclusion}

In Spain, tourism is more important in terms of both employment and gross added value than in any other OECD country. It is a sector that has withstood the worst moments of the recent economic cycle particularly well, and one 
which employs a greater proportion of some of the groups for which work variables register their worst values in aggregate terms (women, younger people, immigrants).

This article concentrates on Spanish tourism human capital. First of all, the results corroborate that the returns that workers obtain in exchange for their investment in an additional year of official training are much lower in the case of tourism activities than in the rest of the sectors (2.6\% and $5.2 \%$, respectively, according to the results from the parsimonious specification of the Mincer earnings regression for the period 2008-2010), a result that has proved to be robust to the inclusion of additional explanatory variables. The study reveals an apparent paradox: over-education (that is, the existence of workers whose level of training is higher than that required to perform the tasks inherent to the job position that they occupy) is greater in this sector than in the rest of the economy, while the relative weight of those workers with higher levels of education is much less than in other sectors, especially with regards to university degrees. The results show that over-educated workers are subject to a wage penalty in relation to those who, with the same training, occupy positions that are more appropriate to their level of education. In a sector where human capital is fundamental, the lower levels of satisfaction with working conditions associated with this phenomenon could be particularly negative, not only in terms of the individual well-being of workers but also in terms of productivity levels and aspects related to the quality of the service provided. It is also worth mentioning that the earnings premium associated with work experience in tourism is approximately half that of the rest of the sectors, and in fact this variable is not significant for female workers.

Secondly, in the context of the global economic crisis, the gap between the returns in the tourism sector and in the rest of the economy has widened, to the extent that the wage return for each additional year of schooling in the period 2008-2010 is only half that obtained in the rest of the Spanish economic sectors, whereas in the preceding year it accounted for around $70 \%$. This is due to a significant reduction in such returns among tourism workers: 2.6 compared to 3.4. One possible limitation of this result is the heterogeneity associated with the fact that the comparison was made between the period 2008-2010 and the year 2007 due to the absence of relevant data for 2005 and 2006. However, the estimated returns for 2007 are extremely close to comparable estimations conducted in a previous analysis for the period 1999-2002 (3.3), something that allays initial concerns and supports the robustness of this result. One tentative explanation for this increasing gap could be related to the behaviour of employment in this sector during the recession: it remained stable between 2007 and 2010, while it decreased by $8.2 \%$ for the Spanish economy as a whole. The adjustment in the Spanish labour market took place largely through a high level of job destruction whereas in tourism activities, wage restraints have been applied, which may have differentially and negatively affected the returns to education of the workers in this sector. This interpretation is coherent with the evolution of hourly earnings: on average, they increased by $6.22 \%$ between 2007 and 2008-2010 for tourism workers, while the figure was $9.51 \%$ for those working in the rest of the sectors. However, in the case of those holding university degrees, hourly earnings in tourism did not change, whereas they grew by $7.28 \%$ in the rest of the economy. As a result of this evolution, the 
difference in average hourly earnings between the group of workers holding university degrees and those whose highest completed educational level is primary education decreased between both periods from around 51\% to $33 \%$ for tourism workers, while it remained stable (around 70\%) for the rest of the economy.

The calculation of the returns to education is a relevant tool for successful planning of both individuals' and policy makers' actions in the education and labour markets. Among the very diverse social and individual implications of the results of this study, two are of particular relevance. Firstly, from a global point of view, the incentives for undertaking training are lower in this sector than in others and have decreased during the crisis, which may have contributed to the retention of a large part of tourism's labour force but could also contribute to dissuading more qualified individuals from entering the sector, generating problems of competitiveness in the medium and long-term in a context of growing international competition. One of the implications of this evolution in rates of return on human capital is that it seems necessary from the labour supply point of view to match the levels of education received by students with the real needs of the sector, in order to avoid over-education becoming consolidated as a structural characteristic of the sector. The contributions made by public authorities and the educational community to the sustainable growth of the sector should, particularly in a country such as Spain, focus on improving specialized tourism training at all levels. It is essential to generate synergies with the productive fabric (providing a tourism education capable of responding to the training needs demanded by the business environment), designing general and specific competences that take into account both the professional profiles and the capacities that should be developed in each field of education related to tourism. In terms of demand, it is also necessary to take action with respect to production methods and activities, which should be offered in such a way that the overall level of the quality of employment in the sector is improved. Unquestionably, this represents a long-term strategy, which is difficult to reconcile with the specific circumstances this industry faces on a day-to-day level, given the pressures that it is under, circumstances that lead to giving priority to maintaining costs as low as possible. Within this context, the strategy followed by many tourism companies until now, based on a cheap workforce in a sector in which most jobs require easily acquired and transmitted skills, seems reasonable. It has enabled many companies to ignore issues of productivity, skills development and general workplace enhancement (Baum, 2007). However, this strategy, which has been exacerbated by the crisis, might be difficult to sustain in a global context characterized by the increasing capacity of international competitors where this type of workforce is abundant (European Commission, 2010). It seems reasonable therefore to stimulate demand among tourism employers for human capital gained through education. As pointed out by GarcíaPozo et al (2011), increasing the formal education of the sector's potential employees will be ineffective unless the structure of the jobs undergoes improvements, something that would include appropriate compensations not only in terms of pay but also in the achievement of job satisfaction objectives. This, in turn, would logically lead to the generation of quality jobs in the tourism industry which would counteract preconceived 
notions of generalized precariousness in the sector and make it more attractive to human capital.

Finally, and from a territorial point of view, there is a question that cannot be ignored: tourism activity is not equally important in all regional and local labour markets. Those which are highly dependent on this sector, such as the Balearic or Canary Islands, where more than $20 \%$ of the regional gross domestic product (GDP) is generated by tourism activities, could be at risk of generating an unfavourable perception of education. This, in turn, could generate disincentives among the younger generations or towards the arrival of better qualified immigrants. In this case, the medium and long-term effects on competitiveness would not be limited to the tourism sector but would spill over into the whole of the regional/local economy, since employment expectations would logically be linked to the predominant sectors in the region. This phenomenon could be particularly significant in those cases where the considerable weight of the tourism sector is combined with other low-tech/lowskills sectors such as that of the construction of second homes, as is the case in some of the autonomous regions on the Spanish Mediterranean coast, and could be seriously detrimental to territorial cohesion.

\section{Endnotes}

1 The crisis period in this study covers the years 2008-2010, while the previous period only includes data for 2007 due to the lack of data for 2005, when the survey was discontinued, and 2006, when some key variables (see note 2) were not included in the questionnaire, thus precluding the creation of a pool for a similar number of years to make the comparison. However, it should be noted that the estimated value for the return to education for tourism workers in Table $2(3.4 \%)$ is very similar to the results reported by Lillo-Bañuls and Ramón-Rodríguez (2005), who conducted a comparable analysis based on a pool of four waves of the same statistical source for the period 1999-2002. According to their estimations, the individual return to education in tourism was $3.3 \%$ (the estimated coefficients for the variables experience and squared experience were 0.015 and -0.000 , respectively; all variables were significant at the $1 \%$ level). This similar figure contrasts with the estimated value for the period 2008-2010 (2.6\%, Table 2) and supports the conclusions reached in the paper, despite initial concerns due to the dissimilarity between the number of years included in each of the reference terms used for analysing the recent evolution of returns to education in the Spanish tourism sector.

2 This approach was not feasible for the year 2006 due to the deletion of some variables from the questionnaire, although they were re-introduced in subsequent waves of this survey. This is the main reason why it was not possible to use the data for that year to create the comparison term in the analysis (see note 1).

3 The criteria employed by the Institute of Tourism Studies, based on the codes used in the Spanish National Classification of Economic Activities, were adopted to obtain the sub-sample of those workers employed in activities related to tourism.

4 Among workers in the hotel and restaurant sub-sector, the proportion is as high as $26 \%$. In contrast to these figures is the practical insignificance of under-education, which affects barely $2 \%$ of workers. For their sample of hotel workers (data derived from the researchers' survey in Andalusia), Marchante et al (2003) obtained a level of $17.5 \%$ of over-educated workers, a figure that rises to $61.5 \%$ when university graduates employed in the sector are examined separately. In the sample used in this article, almost half of workers holding university degrees are affected by over-education in tourism activities.

5 Calculated as $\left(\exp \beta_{i}-1\right) \times 100$. See Halvorsen and Palmquist (1980) for the interpretation of dummy variables in semilogarithmic equations.

6 In the hotel and restaurant sub-sector, which employs $65 \%$ of tourism workers, the estimated returns are even lower: $1.9 \%$.

7 This is especially true among female workers (for which the returns decreased by $27 \%$ versus a $15 \%$ reduction among male workers). 
8 Data corresponding to workers registered with the Spanish Social Security system in activities related to tourism and in the economy as a whole (average value for January to December and variation in relation to the previous year) extracted from IET(2009) and the Ministry of Employment and Immigration.

9 According to the statistical source used in the paper, the evolution of hourly earnings by level of education was as follows: firstly, for workers for whom primary education was their highest completed educational level, hourly earnings in 2007 were $€ 6.00$ (tourism) and $€ 6.28$ (rest of sectors), and in the period 2008-2010 the figures were $€ 6.83$ and $€ 6.80$, respectively. Secondly, for workers holding university degrees, hourly earnings in 2007 were $€ 9.08$ (tourism) and $€ 10.71$ (rest of sectors), and in the period 2008-2010 the figures were $€ 9.06$ and $€ 11.49$, respectively.

10 Calculated as $\left(\exp \beta_{i}-1\right) \times 100$.

\section{References}

Aguilar, M.I., and García-Crespo, D. (2008), 'Desajuste educativo y salarios en España', Estadística Española, Vol 50, No 168, pp 393-426.

Ammermueller, A., Kuckulenz, A., and Zwick, T. (2009), 'Aggregate unemployment decreases individual returns to education', Economics of Education Review, Vol 28, pp 217-226.

Baum, T. (2007), 'Human resources in tourism: still waiting for change', Tourism Management, Vol 28, pp 1383-1399.

Becker, G.S. (1964), Human Capital: A Theoretical and Empirical Analysis, With Special Reference to Education, National Bureau of Economic Research, New York.

Brau, R., Lanza, A., and Pigliaru, F. (2007), 'How fast are small countries growing? Evidence from the data for 1980-2003', Tourism Economics, Vol 13, No 4, pp 603-614.

Campos-Soria, J.A., Ortega-Aguaza, B., and Ropero-García, M.A. (2009), 'Gender segregation and wage differences in hospitality industry', Tourism Economics, Vol 15, No 4, pp 847-866.

Campos-Soria, J.A., Marchante-Mera, A., and Ropero-García, M.A. (2011), 'Patterns of occupational segregation by gender in the hospitality industry', International Journal of Hospitality Management, Vol 30, pp 91-102.

Cortés-Jiménez, I. (2008), 'Which type of tourism matters to the regional economic growth? The cases of Spain and Italy', International Journal of Tourism Research, Vol 10, No 2, pp. 127-139.

Di Liberto, A. (2010), High Skills, High Growth: Is Tourism an Exception? Centro Ricerche Economiche Nord Sud (CRENOS), Working Paper 2010/11.

European Commission (2010), Communication from the Commission to the European Parliament, the Council, the European Economic and Social Committee and the Committee of the Regions - 'Europe, the World's No 1 tourist destination - A New Political Framework for Tourism in Europe' [COM(2010) 352 final].

Exceltur (2004), Libro Blanco de los Recursos Humanos en turismo, Exceltur, Madrid.

García Montalvo, J., and Peiró, J.M. (2009), Análisis de la Sobrecualificación y la Flexibilidad Laboral, Fundación Bancaja, Valencia.

García-Pozo, A., Marchante, A.J., and Sánchez-Ollero, J.L. (2011), 'Occupational differences in the return on human capital in the Spanish travel agency and hospitality industries', Tourism Economics, Vol 17, No 6, pp 1325-1345.

García-Pozo, A., Campos-Soria, J.A., Sánchez-Ollero, J.L., and Marchante-Lara, M. (2012), 'The regional wage gap in the Spanish hospitality sector based on a gender perspective', International Journal of Hospitality Management, Vol 31, pp 266-275.

Halvorsen, R., and Palmquist, R. (1980), 'The interpretation of dummy variables in semilogarithmic equations', American Economic Review, Vol 70, No 3, pp 474-475.

IET (Instituto de Estudios Turísticos) (2009), Empleo en el Sector Turístico. Informe Anual 2009, IET, Madrid.

INE (Instituto Nacional de Estadística) (2010) Estadísticas de Enseñanza Universitaria. Año Académico 2008-2009, INE, Madrid.

Lillo-Bañuls, A. (2009a), El Capital Humano Como Estrategia Competitiva en el Sector Turístico Español, IV International prize on touristic studies Gabriel Escarrer, Universidad de Islas Baleares, Edicions UIB.

Lillo-Bañuls, A. (2009b), 'El papel del capital humano en el sector turístico: algunas reflexiones y propuestas', Cuadernos de Turismo, Vol 24, pp 53-64.

Lillo-Bañuls, A., and Casado-Díaz, J.M. (2010), 'Rewards to education in the tourism sector: one step ahead', Tourism Economics, Vol 16, No 1, pp 11-23. 
Lillo-Bañuls, A., and Ramón-Rodriguez, A.B. (2005), 'Returns to education in the Spanish tourism labour market', Tourism Economics, Vol 11, No 1, pp 119-132.

Marchante, A., Ortega, B., and Pagán, R. (2003), 'Desajuste educativo y salarios: nueva evidencia para el caso español', Revista Asturiana de Economía, Vol 28, pp 131-158.

Marchante, A., Ortega, B., and Pagán, R. (2005), 'Educational mismatch and wages in the hospitality sector', Tourism Economics, Vol 11, No 1, pp 103-117.

Mincer, J. (1974) Schooling, Experience and Earnings, NBER, New York (reprinted in 1993 by Gregg Revivals, Aldershot, UK and Brookfield, USA).

Muñoz-Bullón, F. (2009), 'The gap between male and female pay in the Spanish tourism industry', Tourism Management, Vol 30, pp 638-649.

Murillo, I.P., Rahona, M., and Salinas, M.M. (2010), Efectos del Desajuste Educativo Sobre el Rendimiento Privado de la Educación: Un Análisis Para el Caso Español (1995-2006), Fundación de las Cajas de Ahorros, Documento de Trabajo No. 520/2010.

Santos, L.D., and Varejão, J. (2007), 'Employment, pay and discrimination in the tourism industry', Tourism Economics, Vol 13, No 2, pp 225-240.

Thrane, C. (2008), 'Earnings differentiation in the tourism industry: gender, human capital and socio-demographic effects', Tourism Management, Vol 29, pp 514-524.

Thrane, C. (2010), 'Education and earnings in the tourism industry: the role of sheepskin effects', Tourism Economics, Vol 16, No 3, pp 549-563.

Thurow, L.C. (1970), Investment in Human Capital, Wadsworth Pub. Co., Boston, MA. 


\section{Appendix}

Table A1. Description of statistics for main study variables, 2007.

\section{Rest of sectors}

Education (years)

Level of education:

Primary $\left(E_{1}\right)^{*}$

Secondary $\left(E_{2}\right)$

Professional training $\left(E_{3}\right)$

Baccalaureate $\left(E_{4}\right)$

University $\left(E_{5}\right)$

Hourly earnings $(€)$

Experience (years)
10.57

$21.67 \%$

$19.64 \%$

$19.42 \%$

$12.76 \%$

$26.51 \%$

7.88

(4.11)

19.01

(12.25)
Tourism

9.63

$24.64 \%$

$25.79 \%$

$17.05 \%$

$18.05 \%$

$14.47 \%$

7.07

$(3.61)$

17.91

(12.29)

Note: Continuous variables: mean and standard deviation - in parentheses; discrete variables: percentage over total number of employees in tourism/rest of economic activities. "Reference category in regressions in Table 2.

Source: Authors' own calculations based on the Quality of Life at Work Survey (ECVT), 2007 (Ministry of Employment and Immigration). 


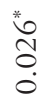

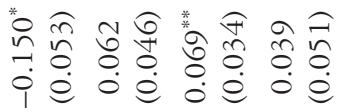

$\stackrel{*}{n} \stackrel{0}{0}$

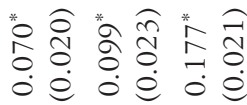

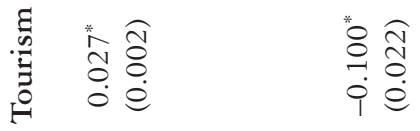

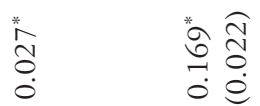

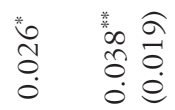

\begin{tabular}{l}
$*$ \\
\multirow{2}{*}{} \\
0
\end{tabular}

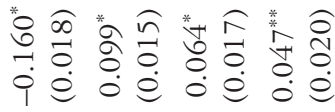

\begin{tabular}{ll}
$*$ & 0 \\
\multirow{2}{*}{} & 0 \\
0 & 0 \\
0 & 0 \\
0 & 0
\end{tabular}

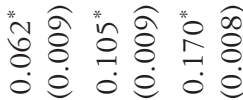

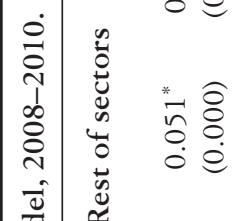

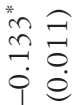

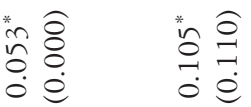

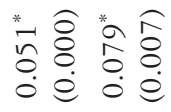

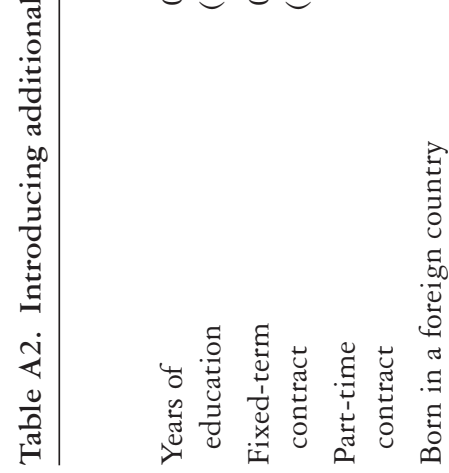

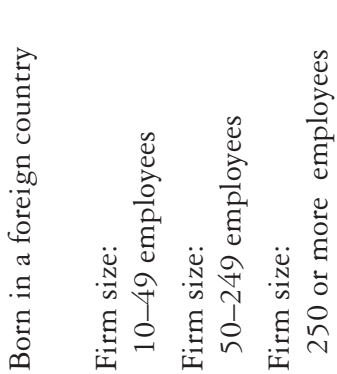

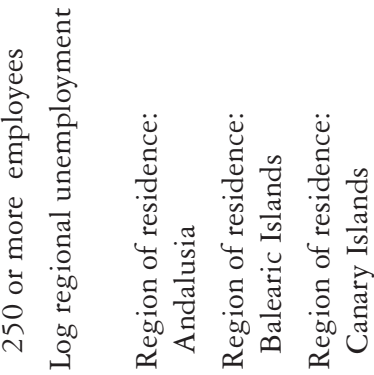




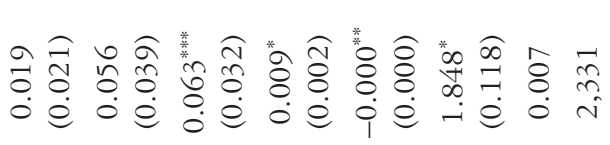

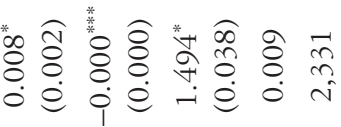

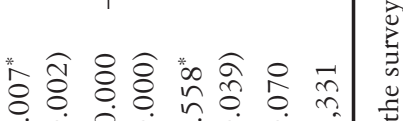

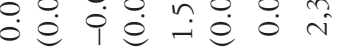

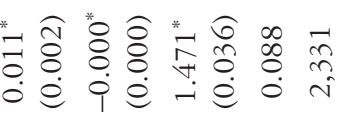

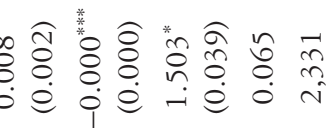

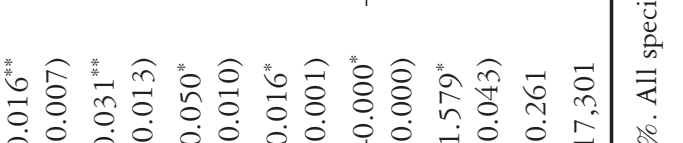

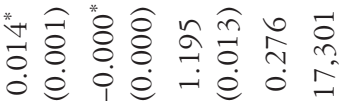

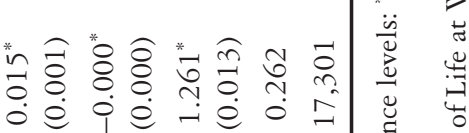
응

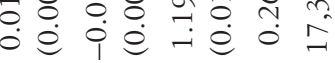
*

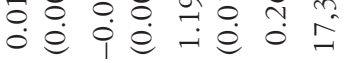

